\title{
Forage performance of Paspalum hybrids from an interspecific cross
}

\author{
Desempenho forrageiro de híbridos de Paspalum obtidos \\ por meio de cruzamentos interespecíficos
}

\author{
Eder Alexandre Minski da Motta $^{\mathrm{I}^{*}}$ Miguel Dall'Agnol ${ }^{\mathrm{I}}$ Felipe Link Nascimento \\ Emerson André Pereira ${ }^{I}$ Juliana Medianeira Machado ${ }^{I}$ \\ Marlon Risso Barbosa ${ }^{\mathrm{I}}$ Carine Simioni ${ }^{\mathrm{I}}$ Priscila Becker Ferreira ${ }^{\mathrm{II}}$
}

\section{ABSTRACT}

The goal of this study was to assess the variability of Paspalum plicatulum x P. guenoarum interspecific hybrids in terms of agronomic performance and their tolerance to cold conditions, as well as to estimate the correlation of different phenotypic characters associated with forage production. Twenty hybrids plants were used, besides one access $P$. guenoarum, one of $\boldsymbol{P}$. plicatulum and the cultivar 'Pensacola' (P. notatum). Assessments were performed on individual plants, in a completely randomized design with five repetitions. Paspalum genotypes presented variability in total dry matter, leaf dry mass, leaf: stem ratio, and tolerance to cold. We suggest selection of the hybrids 08Q01 and 08Q44 for new stages within a forage improvement program. Estimates of phenotypic correlation may aid in the selection of genotypes with better agronomic traits.

Key words: apomixis, native grasses, hybridization.

\section{RESUMO}

O objetivo deste estudo foi avaliar a variabilidade de híbridos interespecificos de Paspalum plicatulum $x \boldsymbol{P}$. guenoarum por meio do desempenho agronômico e tolerância ao frio, bem como estimar as correlações fenotípicas de diferentes caracteres ligados à produção de forragem. Foram utilizados 20 híbridos, um acesso de $\boldsymbol{P}$. guenoarum, um de P. plicatulum e a cultivar 'Pensacola' (P. notatum). As avaliações foram realizadas em plantas individuais, em delineamento completamente casualizado, com cinco repetições. Os genótipos de Paspalum apresentam variabilidade para massa seca total, massa seca de folhas e relação folha: colmo e na tolerância ao frio. É possivel selecionar os híbridos $08 Q 01$ e $08 Q 44$ para novas etapas dentro de um programa de melhoramento de forrageiras. As estimativas de correlações fenotípicas podem auxiliar na seleção de genótipos com caracteres agronômicos superiores.

Palavras-chave: apomixia, gramíneas nativas, hibridação.

\section{INTRODUCTION}

Obtaining cultivars with greater productivity and quality is one of the goals of forageplant improvement programs. These programs aid in the search for new cultivars adapted to diverse edaphoclimatic conditions (JANK et al., 2011). Gramineae belonging to the genus Paspalum are the main constituents of native pasture in the tropical and subtropical regions of the Americas (SARTOR et al., 2009). These species have great intra- and interspecific variability, forage production ability, and nutritional quality, which increase their utility in breeding programs because of their adaptability to different ecosystems. Among the species within this genus, Paspalum plicatulum and Paspalum guenoarum stand out. They have been primarily used as cultivars in Australia, Argentina, and the United States (AGUILERA et al., 2011). In Rio Grande do Sul, Brazil, P. plicatulum presents bromatological characteristics that are compatible with the ruminant production industry, promote tolerance to drought, and increase forage production performance (SCHEFFER-BASSO \& GALLO, 2008). Conversely, P. guenoarum produces forage of good digestibility and tolerance to cold (NABINGER \& DALL'AGNOL, 2008). Both species are considered promising for breeding improvement programs, potentially generating products for use in

\footnotetext{
'Departamento de Plantas Forrageiras e Agrometeorologia, Universidade Federal do Rio Grande do Sul (UFRGS), 90040-060, Porto Alegre, RS, Brasil.E-mail:edermotta87@yahoo.com.br. "Corresponding author.

"Universidade Federal do Pampa (UNIPAMPA), Uruguaiana, RS, Brasil.
} 
cultivated pastures. However, Paspalum notatum cv. 'Pensacola' is the only species from the genus that is used commercially by farmers in southern Brazil, and is one of the few alternatives, in terms of summer perennial species, that is adapted to the edaphoclimatic conditions of this region (PEREIRA et al., 2011; FACHINETTO et al., 2012).

Apomixis is the predominant mode of reproduction among the Paspalum germplasm (QUARÍN, 1992). This reproductive mechanism hinders genetic recombination among species with desired agronomic traits, as well as the protection of cultivars by the Ministério da Agricultura, Pecuária e Abastecimento. Discovery of sexual diploid $\boldsymbol{P}$. plicatulum plants and the subsequent induction of tetraploidy (SARTOR et al., 2009) made genetic improvement of the Plicatula group through interspecific crosses possible. The $\mathrm{F}_{1}$ generation resulting from these crosses may present sexual or apomictic individuals. Once identified, apomictic hybrids could be directed to field trials and, when genotypes with better agronomic traits are obtained, they could be released as new cultivars. Conversely, sexual hybrids could be evaluated and selected for use as new female genitors to obtain better recombinants (AGUILERA et al., 2011; PEREIRA, 2013).

Evaluation of forage traits of interest from new hybrids may lead to the development of progenies with higher forage production and quality, and those better adapted to subtropical conditions. Therefore, the goal of this study was to evaluate the variability of $\boldsymbol{P}$. plicatulum $\mathrm{x} \boldsymbol{P}$. guenoarum interspecific hybrids in agronomic performance and their tolerance to cold, as well as estimate correlations of different phenotypic traits associated with forage production.

\section{MATERIALS AND METHODS}

The experiment was performed in the agricultural years $2011 / 2012$ and $2012 / 2013$, in the municipality of Eldorado do Sul, RS. The experimental area was located in the Brazilian Central Depression region (30'06'02'S and 51'41'27'W, at an altitude of $34 \mathrm{~m})$. The soil was classified as dystrophic red latosol, and the climate type was Cfa, subtropical humid with hot summers, according to the Köppen classification. The average annual temperature was $19.3^{\circ} \mathrm{C}$, with a maximum average of $24.6^{\circ} \mathrm{C}$ in January, and minimum average of $13.8^{\circ} \mathrm{C}$ in June. The average annual precipitation was approximately $1400 \mathrm{~mm}$. During the study period, the precipitation was $747 \mathrm{~mm}$ in the first year and $1012 \mathrm{~mm}$ in the second, and the average temperature was $20.8^{\circ} \mathrm{C}$. A soil analysis was performed preceding the implementation of the experiment. The soil had the following characteristics: $210 \mathrm{~g} \mathrm{~kg}^{-1}$ clay; $\mathrm{pH}$ : 5.4; SMP buffer index $6.3 ; 14 \mathrm{~g}$ $\mathrm{kg}^{-1}$ organic matter; $3.1 \mathrm{cmol}_{\mathrm{c}} \mathrm{dm}^{-3} \mathrm{H}+\mathrm{Al} ; 6.7 \mathrm{mg}$ $\mathrm{dm}^{-3} \mathrm{P} ; 119 \mathrm{mg} \mathrm{dm} \mathrm{dm}^{-3} \mathrm{~K}$; and $\mathrm{Al}, \mathrm{Ca}, \mathrm{Mg}$, and CTC of $0.1,2.0,0.7$, and $6.1 \mathrm{cmol}_{\mathrm{c}} \mathrm{dm}^{-3}$, respectively. Base saturation was $49 \%$; and $\mathrm{Al}$ was $3.2 \%$. The area received base and maintenance fertilization of 20-150-100 and $20-120-100 \mathrm{~kg} \mathrm{ha}^{-1}$ of N-P-K, respectively. A coverage fertilization was performed with $180 \mathrm{~kg} \mathrm{ha}^{-1}$ of $\mathrm{N}$ as urea, fractionated after each cut, according to the technical recommendations for warm season perennial Gramineae, following the recommendations from the Comissão de Química e Fertilidade do Solo - RS/SC, 2004.

Artificial hybridization was performed in a greenhouse during summer 2009 at the Instituto de Botánica del Nordeste (IBONE) at the Universidad Nacional del Nordeste, Corrientes, Argentina. Apomictic genotype Azulão belonging to $\boldsymbol{P}$. guenoarum, native of Rio Grande do Sul, was used as the male genitor. For the female genitor, the sexual tetraploid genotype denominated $4 \mathrm{c}-4 \mathrm{x}$ from P. plicatulum was used (SARTOR et al., 2009). Twenty hybrid plants were obtained from the crosses performed at the IBONE, from which seeds were collected and sent to the Grupo de Melhoramento de Forrageiras do Departamento de Plantas Forrageiras e Agrometeorologia at the Universidade Federal do Rio Grande do Sul (UFRGS). The $F_{1}$ seeds were sown in alveolate trays using a commercial substrate. When the plants presented an average of four tillers, they were transplanted into $1.0 \mathrm{~L}$ pots, where they remained until they were transferred to the fields at the end of spring 2011, along with their genitors. $\boldsymbol{P}$. notatum cv. 'Pensacola' was planted from seedlings as a control. A completely randomized block design was used with five repetitions, and the experimental units were the plants, spaced $1.0 \mathrm{~m}$ apart. Assessments were performed by cutting plants when the majority of the genotypes reached $35-\mathrm{cm}$ tall, and $10 \mathrm{~cm}$ of growth above the ground was left for all the genotypes (PEREIRA et al., 2012), except for cv. 'Pensacola', which was evaluated when it was $20-\mathrm{cm}$ tall and $5 \mathrm{~cm}$ of growth was left (FACHINETTO et al., 2012). Four and five cuts were performed in the first and second year of the study, respectively.

Cut samples were separated into leaves, stems, and inflorescences and were subsequently placed in a forced air oven at $65^{\circ} \mathrm{C}$ until a constant mass was obtained. Measured traits were: total dry mass (TDM, g plant ${ }^{-1}$ ), leaf dry mass (LDM, g plant ${ }^{-1}$ ), and stem dry mass (SDM, g plant $\left.{ }^{-1}\right)$. The leaf: stem 
ratio (LSR, LDM/SDM) was calculated using these variables. In each cut, it was counted the number of tillers (NT). Plant height $\left(\mathrm{PH}, \mathrm{cm} \mathrm{plant}^{-1}\right)$ was measured from the soil to the average bending height of leaves in the canopy, whereas the plant coverage diameter (PCD, cm planta ${ }^{-1}$ ) was estimated using the average coverage diameter for each plant (ACUÑA et al., 2009; PEREIRA, 2013). Approximately five days after each cut, visual notes were made concerning new sprouts using a scale from 1 to 5 , with 1 denoting lower re-growth ability and 5 indicating the best (PEREIRA, 2013). During the winter of the first year, on June 21 and July 26 2012, visual notes were made for the tolerance to cold (TCold) using a 1-5 scale, with 1 indicating lower tolerance and 5 the greatest (ACUÑA et al., 2009; PEREIRA, 2013). Traits NT, PH, PCD, and re-growth were part of the phenotypic correlation analyses. An analysis of variance (ANOVA) was performed with the MIXED procedure in the statistical program $\mathrm{SAS}^{\circledR}(2001)$. Twelve variance and covariance matrix structures were tested, as follows: Variance Component (VC), Compound Symmetry (CS), Unstructured (UN), First-order Autoregressive (AR [1]), Heterogeneous First-order Autoregressive (ARH [1]), Heterogeneous Compound Symmetry (HCS), Toeplitz (TOEP), First-order Autoregressive Moving Average (ARMA $[1,1]$ ), Ante-dependence First-order (ANTE[1]), Unstructured Correlation (UNR), Banded Main Diagonal (UN [1]), and Huynh-Feldt (H-F). Selection of the best matrix structure was made based on the Akaike information criterion (AIC; AKAIKE, 1974), Bayesian information criterion (BIC; SCHWARZ, 1978), restricted likelihood algorithm (-2LMR), Mean Square Error (MSE). The best matrices were selected through the AIC and BIC criteria, and the likelihood test. Means were estimated using the LSMEANS procedure and the means were compared using the Tukey-Kramer test at 5\% significance. Subsequently, the variables were subjected to the Pearson correlation analysis.

\section{RESULTS AND DISCUSSION}

The variance and covariance matrices that converged for the model were UN, ANTE (1), UNR, UN (1), and VC for all years and parameters analyzed. The matrix used in this analysis was VC, which presented lower indices of AIC, BIC, -2LMR, and MSE. There was an interaction between genotypes and years, which indicated there was variability in production performance of different genotypes across study years. Similar results were observed for
P. lepton (PEREIRA et al., 2011), P. guenoarum, and $\boldsymbol{P}$. notatum (PEREIRA et al., 2015). According to FACHINETTO et al. (2012), it is important to perform evaluations in different years to address this interaction, because genotypes may respond differently in different years at the same location.

For the TDM production trait, 14 hybrids and the Azulão genotype performed better than the genotype 4c-4x and cv. 'Pensacola' in the first year (Table 1). In the second year, the Azulão genotype performed better than all genotypes. This genotype was used in the crosses because it presented high forage production potential (PEREIRA et al., 2015) and tolerance to cold (FACHINETTO et al., 2012). The lower production of TDM of the hybrids in relation to the Azulão genotype may have been caused by the low capacity of the combination between the genitors, which resulted in lowered hybrid vigor in the progenies. Currently, the sexual genotype $4 c-4 x$ is the only genotype that allows for the improvement of species in the Plicatula group by performing interspecific crosses. In the second year, when plants were already well adapted to the field, all hybrids exhibited greater TDM production than cv. 'Pensacola' (Table 1). The following hybrids were notable: 08Q01, 08Q44, 08Q15, 08Q09, and 08Q12. These presented TDM production 6.4, 6.4, $6.0,5.9$, and 5.7 times greater than the commercial cultivar, respectively. Other studies performed with Paspalum species reported greater production than the cv. 'Pensacola'. In a study of the genotypes of P. lepton, PEREIRA et al. (2011) observed TDM production up to 3.9 times greater than that of $\mathrm{cv}$. 'Pensacola'. FACHINETTO et al. (2012) reported that TDM production was 20.7 and 24.8 times greater than the commercial cultivar for the Azulão and Baio genotypes, respectively, belonging to $P$. guenoarum.

For the production character LDM in the first year, 11 hybrids and the Azulão genotype performed greater compared to the $4 c-4 x$ genotype and to cv. 'Pensacola'. In the second year, hybrids 08Q01 and 08Q44 and the Azulão genotype were greater than all the other genotypes (Table 1). These genotypes exhibited LDM production of 9.3, 9.6, and 9.8 times greater than the cv. 'Pensacola'. Similar results were described by SAWASATO (2007) and PEREIRA et al. (2015) when evaluating the Azulão genotype, which underlines its high performance in the production of LDM. Therefore, the results indicated that the use of this genotype as male genitor contributed to the high proportion of leaves grown by the hybrids 08Q01 and 08Q44, particularly in comparison to the commercial cultivar. This 
Table 1 - Total dry mass and leaf dry mass (g plant ${ }^{-1}$ ) of genotypes from the genus Paspalum.

\begin{tabular}{|c|c|c|c|c|}
\hline \multirow[t]{2}{*}{ Genotypes } & $2011 / 2012$ & $2012 / 2013$ & $2011 / 2012$ & $2012 / 2013$ \\
\hline & \multicolumn{4}{|c|}{ 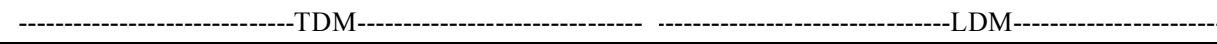 } \\
\hline Azulão & $296 \mathrm{a}$ & $900 \mathrm{a}$ & $160 \mathrm{a}$ & $548 \mathrm{a}$ \\
\hline 08Q01 & $206 \mathrm{ab}$ & $788 \mathrm{~b}$ & $116 \mathrm{a}$ & $537 \mathrm{a}$ \\
\hline 08Q44 & $243 \mathrm{a}$ & $783 \mathrm{~b}$ & $134 \mathrm{a}$ & $518 \mathrm{a}$ \\
\hline 08Q08 & $191 \mathrm{~b}$ & $664 \mathrm{bc}$ & $101 \mathrm{ab}$ & $463 \mathrm{~b}$ \\
\hline 08Q12 & $173 \mathrm{~b}$ & $703 \mathrm{bc}$ & $85 \mathrm{~b}$ & $465 \mathrm{~b}$ \\
\hline 08Q09 & $182 \mathrm{~b}$ & $721 \mathrm{bc}$ & $118 \mathrm{a}$ & $419 \mathrm{bc}$ \\
\hline 08Q15 & $139 \mathrm{~b}$ & $739 \mathrm{bc}$ & $62 \mathrm{bc}$ & $444 \mathrm{bc}$ \\
\hline 08Q32 & $216 a b$ & $655 \mathrm{bc}$ & $103 \mathrm{ab}$ & $403 \mathrm{c}$ \\
\hline 08Q20 & $172 \mathrm{~b}$ & $628 \mathrm{bc}$ & $91 \mathrm{~b}$ & $411 b c$ \\
\hline 08Q42 & $161 \mathrm{~b}$ & $591 \mathrm{c}$ & $75 \mathrm{bc}$ & $393 \mathrm{c}$ \\
\hline 08Q34 & $190 \mathrm{~b}$ & $455 \mathrm{~d}$ & $117 \mathrm{a}$ & $325 \mathrm{c}$ \\
\hline 08Q25 & $110 \mathrm{bc}$ & $491 \mathrm{~cd}$ & $76 \mathrm{bc}$ & $342 \mathrm{c}$ \\
\hline 08Q06 & $153 \mathrm{~b}$ & $552 \mathrm{c}$ & $68 \mathrm{bc}$ & $316 \mathrm{c}$ \\
\hline 08Q23 & $126 \mathrm{~b}$ & $397 \mathrm{~d}$ & $81 \mathrm{~b}$ & $266 \mathrm{~d}$ \\
\hline 08Q33 & $166 \mathrm{~b}$ & 320 de & $90 \mathrm{~b}$ & $217 \mathrm{~d}$ \\
\hline 08Q22 & $75 \mathrm{c}$ & $398 \mathrm{~d}$ & $49 \mathrm{bc}$ & $242 \mathrm{~d}$ \\
\hline 08Q43 & $103 \mathrm{bc}$ & $234 \mathrm{e}$ & $71 \mathrm{bc}$ & $181 \mathrm{~d}$ \\
\hline 08Q05 & $143 \mathrm{~b}$ & $146 \mathrm{f}$ & $87 \mathrm{~b}$ & $112 \mathrm{e}$ \\
\hline 08Q02 & $71 \mathrm{c}$ & $205 \mathrm{e}$ & $50 \mathrm{bc}$ & $141 \mathrm{~d}$ \\
\hline 08Q04 & $67 \mathrm{c}$ & $184 \mathrm{e}$ & $47 \mathrm{bc}$ & $122 \mathrm{~d}$ \\
\hline $4 c-4 x$ & $40 \mathrm{c}$ & $154 \mathrm{f}$ & $32 \mathrm{c}$ & $121 \mathrm{~d}$ \\
\hline 08Q10 & $43 \mathrm{c}$ & $142 \mathrm{f}$ & $28 \mathrm{c}$ & $92 \mathrm{e}$ \\
\hline 'Pensacola' & $48 \mathrm{c}$ & $123 \mathrm{~g}$ & $29 \mathrm{c}$ & $56 \mathrm{f}$ \\
\hline Mean & 144 & 477 & 81 & 310 \\
\hline
\end{tabular}

Means followed by the same letters in columns did not differ from each other according to the Tukey-Kramer test, at $5 \%$ probability.

characteristic is very important, because leaves are the organs responsible for photosynthesis, in addition to being the main source of nutrients for ruminants in pasture systems (RODRIGUES et al., 2008).

In the analysis of LSR during the first year when plants were establishing themselves in the fields, the greatest indices were observed for the hybrids 08Q02 and 08Q43, and the 4c-4x genotype. Furthermore, in the second year, the hybrids $08 \mathrm{Q} 05$ and 08Q43 and the 4c-4x genotype exhibited the greatest LSR, and their LSR was greater than the majority of the hybrids and the Azulão genotype. Hybrids 08Q01 and $08 \mathrm{Q} 44$, which exhibited the greatest productions of LDM, demonstrated the inverse for the LSR. This may be related to the growth habit of each species, as the cespitose habit of these species causes the investment of more resources in the production of supporting structures (stems). However, these hybrids expressed values of LSR greater than cv. 'Pensacola' (Table 2), corroborating the results obtained by PEREIRA et al. (2015), who observed greater LSR for the genotypes of $\boldsymbol{P}$ guenoarum when compared to the commercial cultivar. LSR is a fundamental characteristic in predicting the nutritive value of a forage plant because it represents forage with greater protein content and digestibility, and it is used for the selection of experimental hybrids (TOMICH et al., 2004).

With regard to TCold, three groups were formed according to Tukey-Kramer test (Table 2), with 16 genotypes in the first group, including the hybrids 08Q44 and 08Q01 and the Azulão genotype. The hybrids 08Q33, 08Q34, and 08Q05, and the 4c-4x genotype were in the second group. The last group was comprised of cv. 'Pensacola' and the hybrids 08Q22 and 08Q10. Cultivated in some of the subtropical regions of the world, cv. 'Pensacola' is widely used in Florida and in the southeastern United States because of the ease of propagation by seeds, adaptation to low fertility soils, and tolerance to drought and pasture conditions (NEWMAN et al., 2011). However, these authors stated that this cultivar presented better growth under conditions of high temperature and long days, 
Table 2 - Leaf: stem ratio and tolerance to cold of genotypes from the genus Paspalum.

\begin{tabular}{|c|c|c|c|}
\hline \multirow{2}{*}{ Genotypes } & & & \multirow{2}{*}{ Tolerance to cold } \\
\hline & $2011 / 2012$ & $2012 / 2013$ & \\
\hline 08Q20 & $1.3 \mathrm{~b}$ & $2.2 \mathrm{c}$ & $3.7 \mathrm{a}$ \\
\hline 08Q09 & $1.9 \mathrm{~b}$ & $1.7 \mathrm{~d}$ & $3.6 \mathrm{a}$ \\
\hline 08Q25 & $2.3 \mathrm{~b}$ & $3.2 \mathrm{~b}$ & $3.5 \mathrm{a}$ \\
\hline 08Q32 & $0.9 \mathrm{~b}$ & $1.9 \mathrm{~cd}$ & $3.5 \mathrm{a}$ \\
\hline 08Q06 & $0.8 \mathrm{~b}$ & $1.5 \mathrm{~d}$ & $3.5 \mathrm{a}$ \\
\hline $08 Q 15$ & $0.9 \mathrm{~b}$ & $1.7 \mathrm{~d}$ & $3.4 \mathrm{a}$ \\
\hline 08Q44 & $1.3 \mathrm{~b}$ & $2.2 \mathrm{c}$ & $3.3 \mathrm{a}$ \\
\hline Azulão & $1.1 \mathrm{~b}$ & $1.7 \mathrm{~d}$ & $3.3 \mathrm{a}$ \\
\hline 08Q01 & $1.3 \mathrm{~b}$ & $2.4 \mathrm{c}$ & $3.1 \mathrm{a}$ \\
\hline 08Q12 & $1.0 \mathrm{~b}$ & $2.1 \mathrm{~cd}$ & $3.1 \mathrm{a}$ \\
\hline 08Q23 & $1.9 \mathrm{~b}$ & $2.6 \mathrm{~b}$ & $3.0 \mathrm{a}$ \\
\hline 08Q02 & $3.2 \mathrm{a}$ & $2.9 \mathrm{~b}$ & $2.9 \mathrm{a}$ \\
\hline 08Q43 & $3.3 \mathrm{a}$ & $5.6 \mathrm{a}$ & $2.8 \mathrm{a}$ \\
\hline 08Q04 & $2.3 \mathrm{~b}$ & $2.3 \mathrm{c}$ & $2.8 \mathrm{a}$ \\
\hline 08Q08 & $1.1 \mathrm{~b}$ & $2.6 \mathrm{~b}$ & $2.8 \mathrm{a}$ \\
\hline 08Q42 & $1.0 \mathrm{~b}$ & $2.3 \mathrm{c}$ & $2.8 \mathrm{a}$ \\
\hline 08Q33 & $1.2 \mathrm{~b}$ & $2.4 \mathrm{c}$ & $2.5 \mathrm{~b}$ \\
\hline $4 c-4 x$ & $4.2 \mathrm{a}$ & $4.0 \mathrm{ab}$ & $2.4 \mathrm{~b}$ \\
\hline 08Q34 & $1.8 \mathrm{~b}$ & $2.8 \mathrm{~b}$ & $2.2 \mathrm{~b}$ \\
\hline 08Q05 & $1.5 \mathrm{~b}$ & $3.8 \mathrm{ab}$ & $2.1 \mathrm{~b}$ \\
\hline 08Q22 & $2.3 \mathrm{~b}$ & $1.9 \mathrm{~cd}$ & $1.5 \mathrm{c}$ \\
\hline 'Pensacola' & $1.7 \mathrm{~b}$ & $1.1 \mathrm{~d}$ & $1.4 \mathrm{c}$ \\
\hline 08Q10 & $1.9 \mathrm{~b}$ & $2.1 \mathrm{~cd}$ & $1.3 \mathrm{c}$ \\
\hline Mean & 1.7 & 2.5 & 2.8 \\
\hline
\end{tabular}

Means followed by the same letters in columns did not differ from each other according to the Tukey-Kramer test, at $5 \%$ probability.

where more than $85 \%$ of production occurs during the driest months. Studies performed in Rio Grande do Sul reported a decrease in forage production of this cultivar with the occurrence of low temperatures during the autumn and winter seasons (SAWASATO, 2007; FACHINETTO et al., 2012). Thus, it can be stated that hybridization provided better hybrid vigor for this trait and, consequently, greater tolerance to cold when compared to the commercial cultivar.

In the correlation analysis, the variables LDM and TDM were highly correlated with each other (Table 3). These data suggested that when selecting better genotypes according to TDM production, genotypes with a high proportion of leaves will also be selected, indicating that it would not be necessary to perform morphological separation among genotypes of Paspalum. Correlations between desired traits are fundamental in the genetic improvement process. In this case, selection may be performed in a high heritability trait that is highly correlated with a more complex trait (ARAÚJO \& COULMAN, 2004). When studying genotypes of $\boldsymbol{P}$. lepton and P. guenoarum,
PEREIRA (2013) observed a high correlation between the TDM and LDM traits. According to the author, the association between these characters made possible to observe a greater number of hybrids in the field, increasing the chances to identify and select better genotypes for the production of LDM via indirect selection of TDM production.

The variable NT was positively correlated with PCD, SDM, TCold, and re-growth (Table 3). The NT represents the capacity a plant has in maintaining dense coverage over the soil, which may decrease the incidence of invading plants. High correlation with the PCD variable reinforces the capacity that these genotypes have to cover the soil. The variables NT and PH were not correlated with each other, indicating there was no compensation in density and tiller size. Such compensation is a mechanism in which pastures maintained at lower heights have a greater density of tillers, but of smaller size, whereas pastures maintained at greater heights have a lower number of tillers, but of greater size (BIRCHAM \& HODGSON, 1983). The variable TCold was moderately correlated with the

Ciência Rural, v.46, n.6, jun, 2016. 
Table 3 - Phenotypic correlation coefficients of traits associated with forage production in genotypes from the genus Paspalum

\begin{tabular}{|c|c|c|c|c|c|c|c|c|}
\hline Trait & LDM & LSR & NT & PCD & $\mathrm{PH}$ & SDM & TCold & Re-growth \\
\hline TDM & $0.98^{*}$ & -0.04 & $0.82^{*}$ & $0.80^{*}$ & $0.30^{*}$ & $0.95^{*}$ & $0.31^{*}$ & $0.32^{*}$ \\
\hline LDM & & 0.06 & $0.81^{*}$ & $0.79^{*}$ & 0.24 & $0.89^{*}$ & $0.29^{*}$ & $0.30^{*}$ \\
\hline LSR & & & -0.01 & -0.07 & -0.38 & -0.26 & -0.07 & -0.17 \\
\hline NT & & & & $0.83^{*}$ & 0.24 & $0.76^{*}$ & $0.33^{*}$ & $0.36^{*}$ \\
\hline PCD & & & & & $0.37^{*}$ & $0.76^{*}$ & 0.24 & $0.26^{*}$ \\
\hline $\mathrm{PH}$ & & & & & & $0.43^{*}$ & $0.31^{*}$ & $0.36^{*}$ \\
\hline SDM & & & & & & & $0.34^{*}$ & $0.35^{*}$ \\
\hline TCold & & & & & & & & $0.56^{*}$ \\
\hline
\end{tabular}

${ }^{*}$ Significant $t$-test, at $5 \%$ probability; TDM - total dry mass (g planta $\left.{ }^{-1}\right)$; LDM - leaf dry mass $\left(\mathrm{g}\right.$ plant $\left.{ }^{-1}\right)$; LSR - leaf: stem ratio $(\mathrm{LDM} / \mathrm{SDM})$; SDM - stem dry mass $\left(\mathrm{g}\right.$ plant $\left.{ }^{-1}\right)$; NT - number of tillers (per plant); PCD - plant coverage diameter $(\mathrm{cm})$; PH - plant height $(\mathrm{cm})$; TCold - tolerance to cold.

variable re-growth (Table 3). This fact suggested that the genotypes that tolerate lower temperatures may consequently present better re-growth. In this manner, they are able to reinitiate growth faster at the beginning of the warm season, thus decreasing the forage deficit period (COSTA et al., 2003). ACUÑA et al. (2009) observed that the hybrids of $\boldsymbol{P}$. notatum that showed greater TCold also demonstrated a greater capacity for re-growth.

When considering all the forage traits of interest, the results demonstrated that although the tested progenies did not surpass the Azulão genotype in TDM production, the hybrids 08Q01 and 08Q44 stand out, particularly in production of LDM and TCold. This indicated potential in proceeding with the crossing trials, with the goal of widening the genotype base available to support the improvement program. In addition, they presented greater forage and TCold performance than cv. 'Pensacola', which indicated that these hybrids are promising material for forage production in subtropical regions.

\section{CONCLUSION}

Genotypes of Paspalum present variability in the agronomic traits evaluated and in tolerance to cold. We suggest that the hybrids 08Q01 and 08Q44 should be selected for new stages within a forage-plant improvement program. The estimates of phenotypic correlations may aid in the selection of genotypes with better agronomic traits.

\section{ACKNOWLEDGEMENTS}

We would like to thank Conselho Nacional de Desenvolvimento Científico e Tecnológico (CNPq), Coordenação de Aperfeiçoamento de Pessoal de Nível Superior (CAPES), and SulPasto for the financial support and human resources. Thanks to the IBONE, and Dr. Camilo L. Quarin, for providing the hybrids.

\section{REFERENCES}

ACUÑA, C.A. et al. Bahiagrass tetraploid germplasm: reproductive and agronomic characterization of segregating progeny. Crop Science, v.49, p.581-588, 2009. Available from: <http://www.crops. org/publications/cs/articles/49/2/581 highlight=\&search-result $=1>$. Accessed: Sept. 08, 2013. doi: 10.2135/cropsci2008.07.0402.

AGUILERA, P.M. et al. Interspecific tetraploid hybrids between two forage grass species: sexual Paspalum plicatulum and apomictic P. guenoarum. Crop Science, v.51, p.1544-1550, 2011. Available from: <http://www.crops.org/publications/cs/articles/51/4/1544?hig hlight $=\&$ search-result=1>. Accessed: Sept. 08, 2013. doi: 10.2135/ cropsci2010.10.0610.

ARAÚJO, M.R.A.; COULMAN, B. Genetic variation and correlation of agronomic traits in meadow bromegrass (Bromus riparius Rehm) clones. Ciência Rural, v.34, n.2, p.505-510, 2004. Available from: <http://www.scielo.br/scielo.php?pid=S010384782004000200026\&script $=$ sci_arttext $>$. Accessed: Jan. 15, 2014. doi: $10.1590 / \mathrm{S} 0103-84782004000200026$.

AKAIKE, H. A new look at the statistical model identification. IEEE Transactions on Automatic Control, v.19, n.6, p.716-723, 1974. Available from: <http://ieeexplore.ieee.org/stamp/stamp. jsp?tp=\&arnumber $=1100705>$. Accessed: Oct. 05, 2015. doi: 10.1109/TAC.1974.1100705.

BIRCHAM, J.S.; HODGSON, J. The influence of sward conditions on rates of herbage growth and senescence in mixed swards under continuous grazing management. Grass and Forage Science, v.38, p.323-331, 1983 .

COMISSÃO DE QUÍMICA E FERTILIDADE DO SOLO - RS/ SC. Manual de adubação e calagem para os Estados do Rio Grande do Sul e de Santa Catarina. Porto Alegre: SBCS Núcleo Regional Sul, 2004. 400p.

COSTA, D.I. et al. Morphophysiological and agronomic characterization of Paspalum dilatatum Poir. biotype Virasoro 
and Festuca arundinacea Schreb. 2. Forage availability and nutritive value. Revista Brasileira de Zootecnia, v.32, n.5, p.1061-1067, 2003. Available from: <http://www.scielo.br/scielo. php?pid=S1516-35982003000500005\&script $=$ sci_arttext $>$. Accessed: Jan. 09, 2014. doi: 10.1590/S1516-35982003000500005.

FACHINETTO, J.M. et al. Agronomic evaluation and persistence analysis in a collection of Paspalum notatum Flügge (Poaceae) accessions. Revista Brasileira de Ciências Agrárias, v.7, n.1, p.189-195, 2012. Available from: <http://www.redalyc.org/ articulo.oa? $\mathrm{id}=119023656025>$. Accessed: Jan. 09, 2014. doi: 10.5039/agraria.v7i1a1238

JANK, L. et al. Breeding tropical forages. Crop Breeding and Applied Biotechnology, Special ed, 1, p.27-34, 2011 Available from: <http://www.scielo.br/scielo.php?pid=S198470332011000500005\&script $=$ sci_arttext $>$. Accessed: Oct. 11, 2013. doi: 10.1590/S1984-70332011000500005.

NABINGER C.; DALL'AGNOL, M. Principais gramíneas nativas do RS: características gerais, distribuição e potencial forrageiro. In: SIMPÓSIO DE FORRAGEIRAS E PRODUÇ̃̃O ANIMAL, 3., 2008, Porto Alegre, RS. Anais... Porto Alegre: Departamento de Plantas Forrageiras e Agrometeorologia, 2008. p.7-54.

NEWMAN Y.C. et al. Bahiagrass (Paspalum notatum) Overview and management. Fact Sheet SS-AGR-332. Gainesville, FL: University of Florida Cooperative Extension Service, IFAS, University of Florida, 2011. Available from: $<$ http://edis.ifas.ufl. edu/ag342>. Accessed: Aug. 15, 2015.

PEREIRA, E.A. Melhoramento genético por meio de hibridizações interespecíficas no grupo Plicatula - gênero Paspalum. 2013. 166f. Tese (Doutorado em Zootecnia) - Curso de Pós-graduação em Zootecnia, Universidade Federal do Rio Grande do Sul, RS.

PEREIRA, E.A. et al. Adaptability and stability in apomictic genotypes of the genus Paspalum. Ciência Rural, v.45, n.8, p.1361-1367, 2015. Available from: <http://www.scielo.br/scielo. php?pid $=$ S0103-84782015000801361\&script $=$ sci arttext $>$. Accessed: Sept. 10, 2015. doi: 10.1590/0103-8478cr20130102.

PEREIRA, E.A. et al. Agronomic production of a collection of Paspalum nicorae Parodi access. Revista Brasileira de Zootecnia, v.40, n.3, p.498-508, 2011. Available from: <http://www.scielo. br/scielo.php? pid $=$ S 1516-35982011000300006\&script $=$ sci arttext $>$. Accessed: Dec. 13, 2013. doi: 10.1590/S151635982011000300006

QUARIN, C.L. The nature of apomixis and its origin in panicoid grasses. Apomixis Newsletter, v.5, p.8-15, 1992.

RODRIGUES, R.C. et al. Dry matter production, leaf/stem ratio and growth indexes of palisade grass (Brachiaria brizantha cv. 'Xaraés'), cultivated with different rate combinations of nitrogen and potassium. Revista Brasileira de Zootecnia, v.37, n.3, p.394-400, 2008. Available from: <http://www.scielo.br/scielo. php? pid $=$ S 1516-35982008000300003\&script $=$ sci_arttext $>$. Accessed: Feb. 05, 2014. doi: 10.1590/S1516-35982008000300003.

SARTOR, M.E. et al. Mode of reproduction of colchicine-induced Paspalum plicatulum tetraploids. Crop Science, v.49, p.12701276, 2009. Available from: <http://www.crops.org/publications/ cs/articles/49/4/1270?highlight $=\&$ search-result $=1>$. $\quad$ Accessed: Sep. 08, 2013. doi: 10.2135/cropsci2008.05.0270.

SAS INSTITUTE. Statistical analysis user's guide. Version 8.2. Cary: Statistical Analysis System Institute, 2001.

SAWASATO, J.T. Caracterização agronômica e molecular de Paspalum urvillei Steudel. 2007. 109f. Dissertação (Mestrado em Zootecnia) - Curso de Pós-graduação em Zootecnia, Universidade Federal do Rio Grande do Sul, RS.

SCHEFFER-BASSO, S. M.; GALLO, M. M. Morphophysiological and bromatological aspects of Paspalum plicatulum. Revista Brasileira de Zootecnia, v. 37, n. 10, p. 1758-1762, 2008. Available from: $<$ http://www.scielo.br/scielo.php?pid=S151635982008001000007\&script $=$ sci arttext $>$. Accessed: Aug. 15, 2015. doi: 10.1590/S1516-35982008001000007.

SCHWARZ, G. Estimating the dimensional of a model. Annals of Statistics, Hayward, v. 6, n. 2, p. 461-464, 1978

TOMICH, T.R. et al. Forage potential of sorghum sudangrass hybrids. Arquivo Brasileiro de Medicina Veterinária e Zootecnia, v. 56, n. 2, p. 258-263, 2004. Available from: <http://www.scielo.br/ scielo.php?pid $=$ S0102-09352004000200017\&script $=$ sci arttext $>$. Accessed: Feb. 05, 2014. doi: 10.1590/S0102-09352004000200017. 